\title{
FANCI Gene Mutation
}

National Cancer Institute

\section{Source}

National Cancer Institute. FANCI Gene Mutation. NCI Thesaurus. Code C156023.

A change in the nucleotide sequence of the $\mathrm{FANCl}$ gene. 